June 2019

\title{
Book Review: Palaces for the People: How Social Infrastructure Can Help Fight Inequality, Polarization, and the Decline of Civic Life, Eric Klinenberg
}

Georgia Westbrook

Syracuse University, grw1996@gmail.com

Follow this and additional works at: https://scholarworks.sjsu.edu/ischoolsrj

Part of the American Art and Architecture Commons, American Literature Commons, Archival Science Commons, Art and Materials Conservation Commons, Book and Paper Commons, Cataloging and Metadata Commons, Civic and Community Engagement Commons, Collection Development and Management Commons, Fine Arts Commons, Information Literacy Commons, Intellectual History Commons, Interdisciplinary Arts and Media Commons, Modern Art and Architecture Commons, Museum Studies Commons, Politics and Social Change Commons, Public History Commons, Reading and Language Commons, Scholarly Communication Commons, Scholarly Publishing Commons, Service Learning Commons, Social History Commons, Social Psychology and Interaction Commons, Sociology of Culture Commons, and the United States History Commons

Acknowledgements

$\mathrm{N} / \mathrm{A}$

\section{Recommended Citation}

Westbrook, G. (2019). Book Review: Palaces for the People: How Social Infrastructure Can Help Fight Inequality, Polarization, and the Decline of Civic Life, Eric Klinenberg. School of Information Student Research Journal, 9(1). https://doi.org/10.31979/2575-2499.090105 Retrieved from https://scholarworks.sjsu.edu/ischoolsrj/vol9/iss1/5

This article is brought to you by the open access Journals at SJSU ScholarWorks. It has been accepted for inclusion in School of Information Student Research Journal by an authorized administrator of SJSU ScholarWorks. For more information, please contact scholarworks@sjsu.edu. 
Book Review: Palaces for the People: How Social Infrastructure Can Help Fight Inequality, Polarization, and the Decline of Civic Life, Eric Klinenberg

\section{Keywords}

public libraries, social infrastructure, community space, urban sociology, crisis informatics

\section{Acknowledgements}

N/A

About Author

Georgia Westbrook is an MSLIS candidate at Syracuse University. She holds a BA in art history from Binghamton University. 
Andrew Carnegie called libraries "palaces for the people," and nearly a century after the industrialist's death, his phrase has become the title of sociologist Eric Klinenberg's book about the value of social infrastructure. Palaces for the People: How Social Infrastructure Can Help Fight Inequality, Polarization, and the Decline of Civic Life considers the role of meeting places, including, but not limited to, public libraries, in building social bonds and fostering community resilience and wellbeing. There is much at stake for our increasingly mediated society, but Klinenberg suggests there are still steps we can take to build social infrastructure in a way that dovetails with conflicting political and economic priorities. Palaces for the People provides a critical look into the role of physical spaces for well-being, taking the reader through examples of social infrastructure, making connections to related disciplines, and contextualizing the significance of social infrastructure in times of crisis.

Social infrastructure, as defined by Klinenberg, is "the physical places and organizations that shape the way people interact" (Klinenberg 2018, p. 5). The book opens by looking at the research Klinenberg began while working on his doctorate, studying how social infrastructure affected the outcomes of communities after a significant heat wave in Chicago in 1995. He pays special attention to public libraries, making the point that they allow members of different groups to connect with each other and other groups, including new parents meeting in the children's room and senior citizens joining together to play virtual bowling games. Throughout the book, Klinenberg acknowledges the privileged experiences he has had which might put him at odds with those who rely on social, rather than private, infrastructure. However, he writes again and again of seeking out opportunities to engage through the social infrastructure he describes. He ultimately concludes that even those who are creating products which encourage disconnect and its attendant harms - i.e. online social media networks, like Facebook — would and do benefit from sharing and partaking in a physical community.

A sociologist by training, Klinenberg frames his arguments with paradigms and studies drawn from that discipline. However, there are notes from other fields incorporated in his arguments as well, especially criminal justice. He details the idea of crime prevention through environmental design, a theory which suggests environmental factors make crime less likely in some areas when compared to others (Klinenberg 2018), and the "broken windows" theory, which posits that signs of physical disorder lead to acts of civil disorder, though he questions the latter at length. Klinenberg wonders if the original theory was misguided; what if the focus was on the actual "broken windows" rather than on the crime that might have been occurring nearby? He goes on to cite the work of John MacDonald and Charles Branas, who are working in Philadelphia to build and study community green spaces and their effects in preventing gun violence, as evidence of this new view on the theory.

The book gives equal space to discussion of social infrastructure in times of stability and in times of crisis, both political and physical. Crisis informatics is an increasingly important scholarly field, mainly within library and information science research, which examines the role of information networks and 
technology before, during, and after disasters. Patin (2015) writes that researchers are now focusing on the role library spaces and workers play in natural disasters, rather than only on how to prevent damage to library materials. She writes that after Hurricane Sandy devastated parts of the northeast, the Princeton (NJ) Public Library was a hub for filling out FEMA forms, but also for "responding to information inquiries, creating community contact centres, staffing shelters in the library buildings, housing city command centres, distributing food and supplies, providing power to recharge electronics...providing library materials to evacuees in shelters, and offering meeting space for emergency responders" (Patin 2015, pp. 61-62).

Klinenberg picks up the discussion of community spaces during times of crisis, first with his introduction about the Chicago heat wave and later with a chapter on storms and natural disasters, during which he highlights the ideal of combining social infrastructure with physical infrastructure. While the focus of Palaces for the People tends to be public social infrastructure, Klinenberg at several points mentions the decline of previously strong private social groups, and the resulting importance of social spaces that serve as alternate, albeit casual, meeting spaces. Those connections, Klinenberg argues, are what allow people to weather storms, both metaphorical and literal. They allow people to check in with each other, to make sure they are in good health and safety during natural disasters, and provide resources like supplies and labor, and well-maintained spaces to wait out the storms. To that point, Klinenberg discusses the role of a community church in allowing one family in Houston to recover from Hurricane Harvey. He suggests that, moving forward into an era where climate change is causing more severe damage, communities should follow the leads of cities like Rotterdam, New York, and New Orleans which are working to mitigate that damage by combining social and physical infrastructure. In New York, for example, architects, scientists, and government officials are working together on the Living Breakwaters project to protect Staten Island. That plan includes "natural infrastructure - rocky sloped walls full of finfish, shellfish, and lobsters..." as well as educational programs that bring community members together as stakeholders and collaborators (Klinenberg 2018, p. 203).

Klinenberg is a noted sociologist, and he is currently a professor and the director of the Institute for Public Knowledge at New York University. He has published widely, including several other books for popular audiences focused on the sociology of relationship and networks, including Heat Wave: A Social Autopsy of Disaster in Chicago (2003), Going Solo: The Extraordinary Rise and Surprising Appeal of Living Alone (2012), and Modern Romance (2015), the last of which was written with actor and comedian Aziz Ansari. While written with the popular audience in mind, Palaces for the People is not without the research apparatus of a more scholarly form. It contains an extensive notes section and index, as well as credits for the photos included on the first pages of each of the chapters of the book, most of which were taken by the author or drawn from the public domain.

Palaces for the People is written with the popular audience in mind, though both scholarly audiences and casual readers will find merits in writing 
style and content. Librarians and other information professionals reading the book will likely be affirmed in their current community-focused practices and ideals, but may also find new ways to frame the necessity of their work and new ways to collaborate and expand upon the work they are doing. While the book does not necessarily present discrete steps to take in building and supporting social infrastructure in our communities, there is plenty of inspiration to be taken from Palaces for the People nonetheless. Current discussions of the role of public libraries in social life, and the responsibilities of libraries and communities to each other, will find an important voice in Klinenberg's writing. 


\section{References}

Klinenberg, E. (2018). Palaces for the people: How social infrastructure can help fight inequality, polarization, and the decline of civic life. New York, NY: Crown.

Patin, B. (2015). Through hell and high water: A librarian's autoethnography of community resilience after Hurricane Katrina. Libraries in Crisis, 5(2), 58-83. Retrieved from https://mediatropes.com/index.php/Mediatropes/article/view/26419/19599 